\title{
Lav risiko for leverkreft ved skrumplever
}

\section{Risikoen for hepatocellulært karsinom er liten, også ved levercirrhose, og kreftformen bidrar lite til den høye dødeligheten ved cirrhose.}

Pasienter med levercirrhose har høyere risiko for hepatocellulært karsinom enn normalbefolkningen. Mange pasienter med cirrhose blir derfor undersøkt for leverkreft.

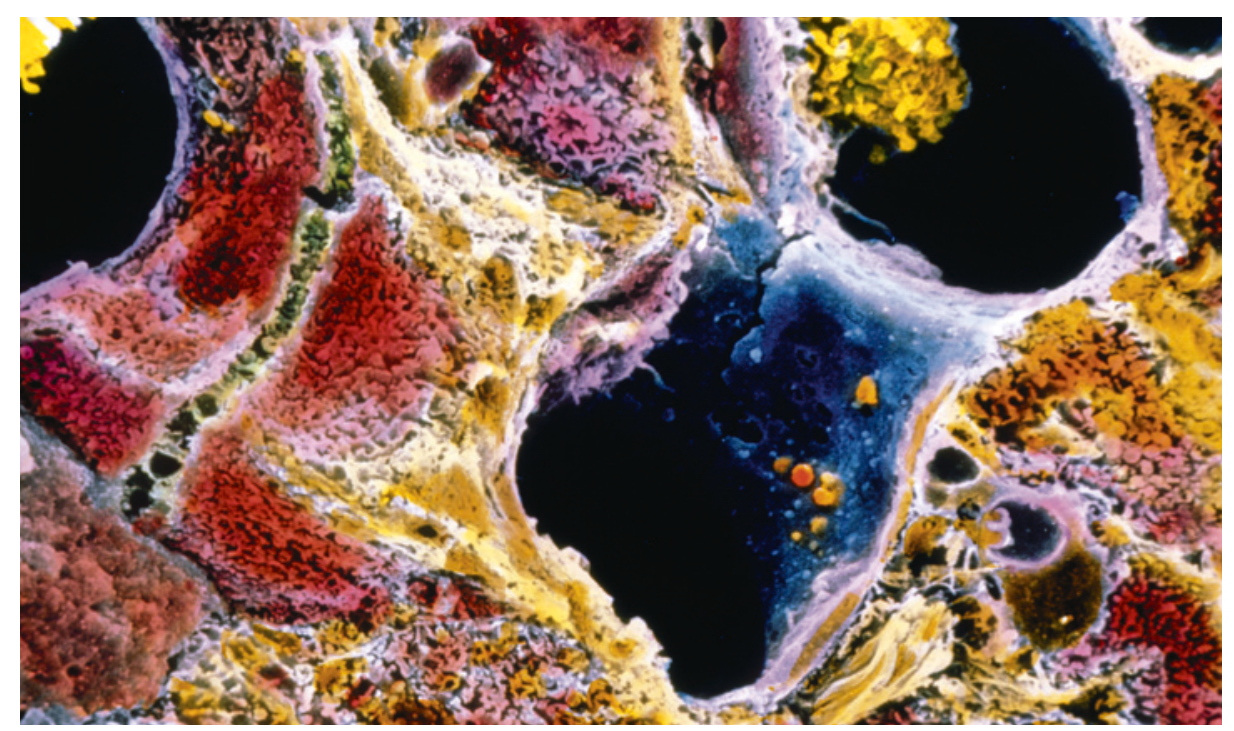

Illustrasjonsfoto Science Photo Library/NTB scanpix
8482 dansker med diagnosen levercirrhose ble identifisert på basis av opplysninger fra sykehusopphold i perioden 1993-2005 (1). Av disse utviklet 163 hepatocellulært

karsinom. 5734 cirrhosepasienter døde i løpet av studieperioden, hvorav 151 med hepatocellulært karsinom. Femårsrisikoen for leverkarsinom var 1,0\%, og femårsmortaliteten var $44 \%$. Bare $1,8 \%$ av dødsfallene var relatert til leverkarsinom. For pasienter som ble fulgt opp av hepatolog, var femårsrisikoen $1,9 \%$ og mortaliteten den samme som for resten av kohorten. Forfatterne konkluderer med at tett oppfølging av cirrhosepasienter med tanke på hepatocellulært karsinom neppe er kostnadseffektivt.

- Oppfølging av cirrhosepasienter med tanke på leverkreft er komplisert og omstridt, sier professor Kristian Bjøro ved Oslo universitetssykehus, Rikshospitalet. Man skal være forsiktig med å si at slik oppfølging ikke har noen hensikt. At hepatocellulært karsinom er sjeldent, også ved cirrhose, og bidrar lite til dødeligheten for gruppen som helhet, utelukker ikke at enkeltpasienter kan ha nytte av å få stilt diagnosen tidlig, sier Bjøro.

\section{Petter Gjersvik \\ petter.gjersvik@gmail.com \\ Tidsskriftet \\ Litteratur \\ . Jepsen P, Ott P, Andersen PK et al. Risk for hepa- tocellular carcinoma in patients with alcoholic cirrhosis: a Danish nationwide cohort study. Ann Intern Med 2012; 156: 841 -7, W295.}

\section{Stamceller sørger for reparasjon av epidermis}

\section{Stamceller og progenitorceller bidrar på hver sin måte i fornyelse av epidermis.}

Epidermis består av et basallag med prolifererende celler og flere lag med differensierte celler som etter hvert avstøtes fra hudoverflaten. Ulike teorier har vært fremsatt for å forklare hvordan celletapet kompenseres. Belgiske og britiske forskere har nå studert celleproliferasjonen i epidermis i en musemodell (1).

Ved bruk av spesielle merketeknikker oppdaget de to distinkte, prolifererende cellepopulasjoner som bidrar til homøostase og reparasjon på ulike måter. Disse består av stamceller, som deler seg langsomt, og progenitorceller, som deler seg raskere. Mens progenitorcellene inngår i det normale vedlikeholdet, er det bare stamcellene som bidrar i vesentlig grad i sårheling.

- Huden er svært interessant for stamcelleforskere, sier professor Jan E. Brinchmann, som er seksjonsleder ved Immunologisk institutt, Oslo universitetssykehus og forskningsgruppeleder ved Nasjonalt senter for stamcelleforskning. - Det er først og fremst stamceller $\mathrm{i}$ hårfolliklene som har vært studert, mens man i denne studien har undersøkt stamceller og progenitorceller i epidermis, sier han.

- De finner en populasjon stamceller i epidermis' basale lag som under normale forhold deler seg bare 4-6 ganger i året. Ca. halvparten av disse cellenes datterceller blir nye stamceller, dvs. identiske kopier av morcellen, mens den andre halvparten blir progenitorceller, som deler seg hver 6. dag. Det mest overraskende er at stamcellene, tilsynelatende uten bidrag fra progenitorcellene, gir opphav til celler som tilheler skader. Dette funnet av langsomtdelende stamceller likner på tilsvarende funn fra cornea, hårfollikler, blod, muskler og hjerne, men er forskjellig fra funn fra oesophagus. Studiens sisteforfatter, Cedric Blanpain, ble nylig kåret til årets mest lovende unge stamcelleforsker, sier Brinchmann.

\section{Trine B. Haugen \\ trine.b.haugen@hioa.no \\ Tidsskriftet}

\section{Litteratur}

1. Mascré G, Dekoninck S, Drogat B et al. Distinct contribution of stem and progenitor cells to epidermal maintenance. Nature 2012; 489: 257-62. 